\title{
INHERITANCE AND WOMEN'S LABOUR IN AFRICA
}

\author{
$J A C K$ GOODY and JOAN BUCKLEY
}

\begin{abstract}
AFRICA is notable for the extent to which women participate in cultivation. An A examination of the contribution of men and women by means of 'The Ethnographic Atlas (Ethnology, 1967) shows that women play the major part in cultivation in 45 per cent of societies in Africa as a whole, and in 53 per cent of sub-Saharan societies. We are concerned here with the contribution women make to cultivation (in pastoral as well as purely farming economies) and not to its over-all control, which is largely in the hands of men.
\end{abstract}

\section{TABLE I}

The division of labour in African agriculture

\begin{tabular}{llllll}
\hline \multicolumn{5}{c}{ Major part in cultivation played by: } \\
\cline { 2 - 6 } & Women & Equal & Men & $\begin{array}{l}\text { No } \\
\text { Agriculture }\end{array}$ & Total \\
\hline All Africa & 126 & 73 & 71 & 9 & 279 \\
& $(45 \%)$ & $(26 \%)$ & $(25 \%)$ & $(3 \%)$ & $(100 \%)$ \\
Sub-Saharan & 124 & 59 & $4 \mathrm{r}$ & 8 & 232 \\
& $(53 \%)$ & $(26 \%)$ & $(18 \%)$ & $(3 \%)$ & $(100 \%)$ \\
\end{tabular}

N.B. Codes: All Africa includes those African societies classified as Circum-Mediterranean in the Ethnographic Atlas. Sub-Saharan Africa excludes them.

Predominance in cultivation is coded on Col. $6_{2}: F, G=$ Women; $M, N=$ Men; $E, D=$ Equal participation.

An investigation of the reasons behind the part played by women in hoe agriculture is not the prime purpose of this paper, but it is possibly connected with their role in hunting and gathering economies. There is a striking uniformity about the division of labour in such societies: men hunt, women gather; men manage the more complex techniques, while women do basketry, fishing, and gather shell fish (Murdock, 1968: 33\%). As Steward has remarked, this sexual complementarity of labour is a marked feature of all hunting societies, with the gathering activities of women often supplying a large proportion of the diet (1968:330). If at the hunting stage women were the ones who collected vegetable produce, they would tend to be the ones concerned with cultivating the domestic varieties of these plants; just as men, who had formerly been concerned with hunting wild animals, would tend to take over the husbandry of domestic livestock. Thus in simpler systems of agriculture-those cultivating the ground by means of the wooden digging stick, ${ }^{1}$ the stone hoe or an iron blade - the fields would tend to be cultivated by women, though the

I See for example, Stauder, $1971: 46$, table 2. 
physically stronger male sex is often called upon to perform some of the heavier tasks. ${ }^{\text {I }}$

There is a marked contrast between sub-Saharan Africa, where men cultivated the land with the hoe, and the societies of North Africa bordering the Mediterranean and the Red Sea, where the plough was in regular use. For almost everywhere the animal-drawn plough falls within the province of the man;2 indeed this is usually the case with the hunting and husbandry of animals as well, though women sometimes take charge of smaller livestock.

The role of women in African agriculture contrasts strongly with Europe and Asia, where the widespread presence of the plough means that males play a dominant part, at least in the preparation of the fields. It is important to note that when one finds the hoe in Asia, especially in the societies of South-East Asia, it is usually women who play the major part (Boserup, 1970). The association between male dominance and intensive agriculture (in which the plough is the most important contributive factor) is evident from Table II : men play a predominant role in only 30 out of 176 societies with extensive agriculture ( 17 per cent), whereas the figure for intensive systems is $4 \mathrm{r}$ out of 94 (44 per cent). This difference in the sexual division of labour is related to other variations noted in earlier publications (Goody, 1969; 1970); from the present standpoint the most important of these associations are of monogamy and diverging devolution (the passage of property to both sons and daughters) with intensive agriculture on the one hand, and of polygyny and 'homogeneous' inheritance (whether patrilineal or matrilineal) with extensive farming on the other. These correlations are confirmed within the African continent. Diverging devolution occurs in areas subject to Islamic and Christian influence, especially the Circum-Mediterranean, where plough agriculture is found, while homogeneous inheritance prevails among the hoe farmers of Black Africa. And while polygyny is allowed in Islamic societies, the rates of plural marriage are very small compared with those found in sub-Saharan Africa.

The main problem that concerns us, however, is not the predominant part played by women in hoe agriculture, which has been recently discussed by Boserup (1970) in similar terms, but variations in the male and female contributions within African systems of hoe agriculture. This problem leads to a discussion of the relationship of the extent of the female contribution to types of economy, inheritance and descent.

First let us deal with the spatial distribution. The degree to which women participate in agricultural work is not the same throughout the continent (Map I). Women play the predominant role in the Congo and in East, Central and South Africa; in these regions there are few societies where the contribution of men equals, much less outweighs that of women. It is in the savannah areas of West Africa that the significance of women in agriculture declines; either men contribute most or there is equal participation.

1 In describing the division of labour by sex in terms of male and female activities, we are not implying that only physiological factors are relevant; we accept that for some purposes, the classification suggested by Brown (1970) and others into childless and child-rearing adults may be more relevant. In a comment upon Brown's paper, Williams describes the activity distinction as one between tasks where children can accompany adults and those where they would hamper the worls; she finds a parallel dichotomy among other primates ( $197 \mathrm{r}$ ).

2 One exception is among some 'pagan' groups in the Hindu Kush e.g. the Kam (Robertson, 1896 : 549). 
Leaving on one side for the moment any comment upon this distribution, let us turn to the second point, the relation of the division of labour to systems of economy, inheritance and descent. What are the implications of this difference in the sexual division of labour? It might be supposed that the cultivation of land by women would lead to the inheritance of land between females, or at least to its transmission through them, that is, matrilineally (to a full brother or sister's son). As far as we know, there was no transmission of land between women in pre-colonial African societies

TABLE II

Type of agriculture and the division of labour in Africa

\begin{tabular}{|c|c|c|c|}
\hline & \multicolumn{3}{|c|}{ Agriculture } \\
\hline & Intensive & Extensive & Total \\
\hline $\begin{array}{l}\text { Male labout } \\
\text { predominant }\end{array}$ & $\begin{array}{l}4 \mathrm{I} \\
(58 \%)\end{array}$ & $\begin{array}{l}30 \\
(42 \%)\end{array}$ & $\begin{array}{l}71 \\
(100 \%)\end{array}$ \\
\hline $\begin{array}{l}\text { Equal } \\
\text { participation }\end{array}$ & $\begin{array}{l}28 \\
(39 \%)\end{array}$ & $\begin{array}{l}45 \\
(61 \%)\end{array}$ & $\begin{array}{l}73 \\
(100 \%)\end{array}$ \\
\hline $\begin{array}{l}\text { Female labour } \\
\text { predominant }\end{array}$ & $\begin{array}{l}25 \\
(20 \%)\end{array}$ & $\begin{array}{l}\text { ror } \\
(80 \%) \\
\text { Total of Table }\end{array}$ & $\begin{array}{l}126 \\
(100 \%) \\
270\end{array}$ \\
\hline \multirow[t]{2}{*}{$\begin{array}{l}X^{2}=29 \cdot 29 \\
p<\cdot 001\end{array}$} & & $\begin{array}{l}\text { No Agriculture } \\
\text { N.I. on Division } \\
\text { of Labour }\end{array}$ & $\begin{array}{r}9 \\
16\end{array}$ \\
\hline & & & 295 \\
\hline
\end{tabular}

N.B. Codes: Predominant part in cultivation as in Table $\mathrm{I}$.

Type of agriculture is coded on Col. 28;

$\mathrm{I}, \mathrm{J}=$ Intensive; $\mathrm{C}, \mathrm{E}=$ Extensive

apart from cultivation rights. ${ }^{\mathrm{I}}$ As we have remarked, agriculture was by and large under the control of men, even where women did most of the work. However, the division of agricultural labour does have some association with the linearity of inheritance. The contribution of women to agricultural production is greater where the basic means of production, land, is inherited matrilineally, than it is in patrilineal systems; and female predominance is virtually never found with diverging devolution (i.e. 'bilateral inheritance'). With matrilineal systems, women are found to play a major part in agriculture about four times as often as men (and twice as great as equal participation). With patrilineal inheritance, women play the major role just under twice as frequently as men (or as men and women participate equally); while with diverging devolution, the cases of male predominance greatly outnumber those of female predominance (and to a lesser extent those where participation is equal). Similar proportions are found if instead of using immovable property (land), we tabulate the division of labour against the inheritance of movables. We note that where matrilineal societies provide exceptions to the predominance of women in

I For example, among the matrilineal, uxorilocal Yao of Malawi, village headmen 'apportioned the land to wardens of sorority-groups who divided it amongst individuals' (Mitchell, 1950: 6). However, cultivation rights seem to have passed from mother to daughter. 
agricultural labour, these tend to be found in West Africa, which is the area where male labour prevails generally. ${ }^{\mathrm{I}}$

There is, then, a tendency for female predominance in hoe agriculture to be associated with matrilineal systems of inheritance, and hence with matrilineal descent

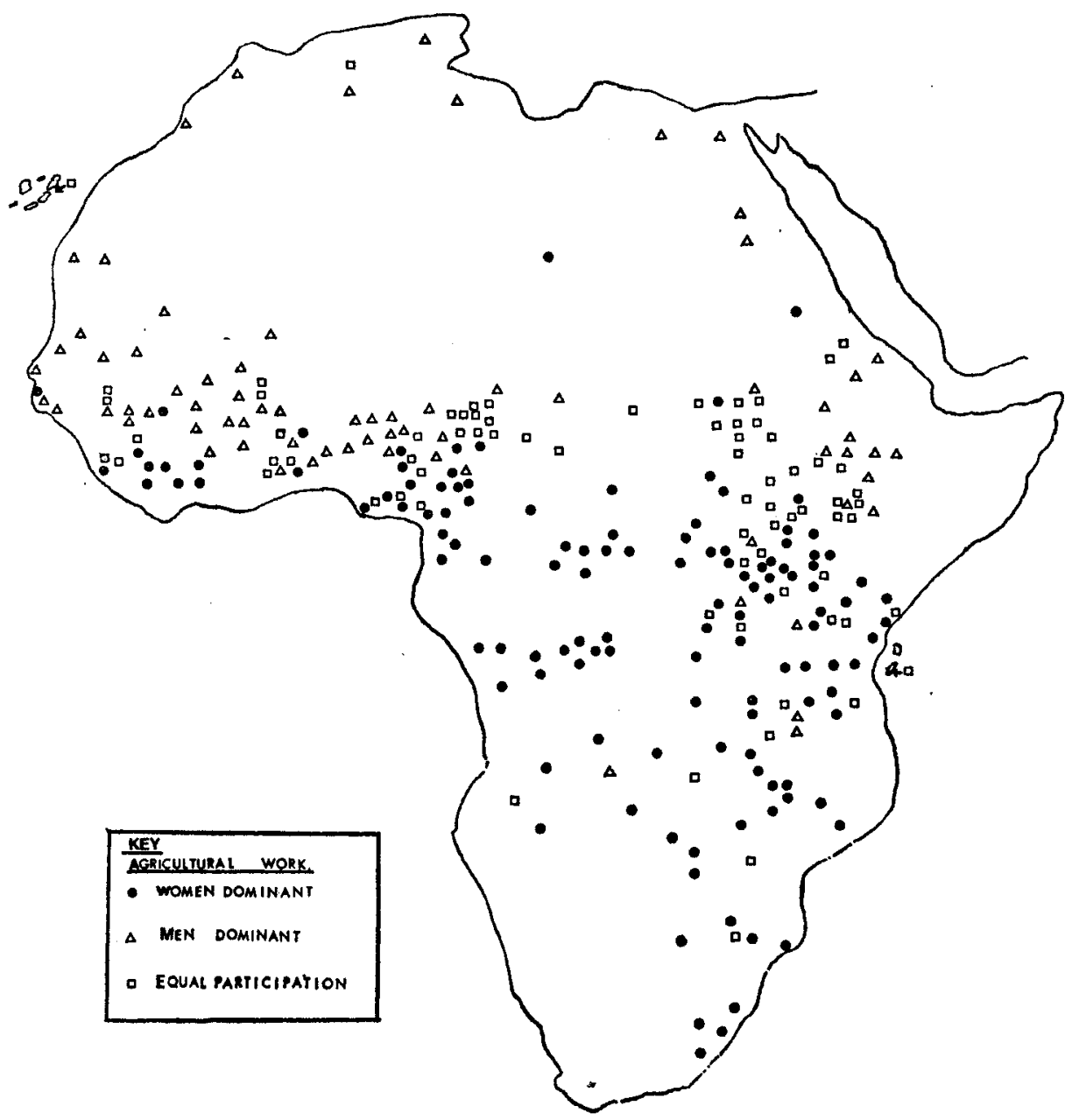

MAP 1. The division of labour in agriculture (based on the Ethnogtaphic Atlas 1967).

groups. Indeed the prevalence of hoe agriculture in Africa may be associated with the greater frequency of matrilineal societies (as against other continents). However, most African societies that practice hoe agriculture or female farming are marked by patrilineal inheritance and descent. Does this form of the division of labour have any influence upon patrilineal institutions?

One difference is revealed in our survey, namely, the link between female farming in patrilineal societies and vertical inheritance. In Africa, lateral systems of

\footnotetext{
I e.g. the matrilineal Coniagui and Bassari, see Lestrange, I955.
} 
transmission, whether of property or office, have a widespread distribution. This is especially so in comparison with Europe and Asia, where property and office tend to pass directly to sons and daughters rather than laterally to brothers. Many Eurasian societies have diverging devolution, which is necessarily vertical. In Africa, matrilineal societies are marked by lateral inheritance; as is the case elsewhere, it is usually a full brother that inherits before a sister's son. But in patrilineal societies, inheritance is sometimes lateral and sometimes vertical. Vertical inheritance is often found where women make the major contribution to agriculture.

TABLE III

Mode of inheritance of land and division of labour in African agriculture

\begin{tabular}{cllll}
\hline & \multicolumn{4}{l}{ Major part in cultivation played by: } \\
\cline { 2 - 5 } & Women & Equal & Men & Total \\
\hline Diverging & $\mathrm{I}$ & 4 & $\mathrm{I} 4$ & $\mathrm{19}$ \\
Inheritance & $(5 \%)$ & $(21 \%)$ & $(74 \%)$ & $(100 \%)$ \\
Patrilineal & 74 & 46 & 45 & 165 \\
Inheritance & $(45 \%)$ & $(28 \%)$ & $(27 \%)$ & $(100 \%)$ \\
Matrilineal & 17 & 9 & 4 & 30 \\
Inheritance & $(57 \%)$ & $(30 \%)$ & $(13 \%)$ & $(100 \%)$ \\
& & Total of Table & 214 \\
& & No Rule of Inheritance & 15 \\
$\mathrm{X}^{2}=23.63$ & & N.I. on Inheritance & 50 \\
$\mathrm{p}<.001$ & & N.I. on Division of Labour & 16 \\
& & & 295 \\
\end{tabular}

N.B. Codes: Predominance in Agriculture as in Table I. Land Inheritance is coded on Col. 74: $C, D=$ Diverging Inheritance; $\mathrm{P}, \mathrm{Q}=$ Patrilineal Inheritance; $\mathrm{M}, \mathrm{N}=$ Matrilineal Inhetitance.

What is it about these patrilineal societies that militates in favour of this type of transmission? When women play a major (or at least an equal) part in agriculture, they do not control the land that they are cultivating. In.matrilineal societies, with female farming, at least the land passes through women. But in patrilineal ones, it is transferred neither between nor through them. Hence male property has to be assigned to them in some way so that they may carry out the basic tasks of food production. While such assignment of property does not give the woman the right to inherit, it does appear to affect the position of her children. With female farming, the tendency is for inheritance to be vertical, that is, to pass to sons before brothers. On the other hand with male farming, there is a much higher proportion of lateral inheritance, that is, brothers inherit before sons. At least, while personal possessions and property acquired by a man's own efforts often pass directly to sons, land and other important property usually form part of a joint estate in which all members of the group concerned hold rights. Control over the property and allocation of resources is held by the senior male, and this position passes laterally to members of the same generation before descending to the next generation. In contrast, in patrilineal 
societies where women have a major role in agriculture, land is more likely to be distributed directly to the children of the union. Indeed, a man may well inherit rights in the particular plots his mother has cultivated. So we find the situation, which is a feature of the widespread polygyny, characteristic of Africa, whereby a man's property is divided between his children per stirpes, according to their maternal origin, i.e. the type of inheritance that Gluckman called the 'house-property complex' when he first drew attention to this mode of property arrangement (1950).

TABLE IV

Type of patrilineal inheritance of land and the division of labour in Africa

\begin{tabular}{cllll}
\hline & \multicolumn{4}{l}{ Major part in cultivation played by : } \\
\cline { 2 - 5 } & Women & Equal & Men & Total \\
\hline Vertical & 60 & 35 & 25 & 120 \\
Inheritance & $(50 \%)$ & $(30 \%)$ & $(20 \%)$ & $(100 \%)$ \\
Lateral & $\mathrm{I4}$ & $\mathrm{Ir}$ & 20 & 45 \\
Inheritance & $(32 \%)$ & $(25 \%)$ & $(43 \%)$ & $(100 \%)$ \\
& & Total in Table & 165 \\
& & Matrilineal Inheritance & 30 \\
& & Diverging Inheritance & 19 \\
$X^{2}=9.56$ & & No Rights/Rule & 15 \\
$\mathrm{p}<.01$ & & N.I. on Inheritance & 50 \\
& & N.I. on Division of Labour & 16 \\
\hline
\end{tabular}

(If matrilineal inheritance is included, $\mathrm{X}^{2}=6.39, \mathrm{P}<\cdot 05$ )

N.B. Codes: Predominance in cultivation as in Table I. Inheritance of land is coded on Col. 74, P = Vertical Inheritance; $\mathrm{Q}=$ Lateral Inheritance.

The sons of one woman, as opposed to sons of a co-wife, may have specific rights connected with the distribution of that part of the husband's property that their mother herself has worked. Of course, maternal affiliation is an important principle of segmentation in most systems of patrilineal descent groups. In his classic analysis of the lineage system of the Nuer, Evans-Pritchard comments upon the importance of maternal differentiation in the domestic and political spheres. He notes that there is a fundamental cleavage within the agnatic sibling group between the children of different mothers, so that a 'lineage bifurcation is a polygamous family writ large' (1940: 247). Indeed it is to this differentiation that Evans-Pritchard appears to refer when he writes of the paradox of agnatic descent being traced through women, a point that has caused much critical comment, some of which arises from a failure to appreciate the point being made. ${ }^{I}$ Other aspects of maternal differentiation within the

I For Schneider, it is one of 'those special gems of paradoxical obfuscation for which EvansPritchard is justly famous' (1965: 74). EvansPritchard's use of descent (e.g. I95 I: 28) partly sontributes to the misunderstanding, but the com- mentator's judgement seems unnecessarily harsh. At the time Evans-Ptitchard was writing, the distinction had not been clearly elaborated (see Barnes 1971 : 155). 
agnatic unit have been discussed by Firth (1936) and Fortes (1949). I However, the house-property complex utilizes the division between wives in a polygynous household for the transmission of property and appears to be connected with the system of cattle-linked siblings, where brothers may have prior claim to the bridewealth received for uterine sisters. Property-land, movables or both-is assigned to a particular wife and inherited by her sons. Inheritance is patrilineal but specific rights in the patrimony are transmitted through women, whose status as wives (not as sisters, as would be the case in a matrilineal system) is important in determining the heritage of their sons.

We were unable to test the suggested association between female farming and the house-property complex in patrilineal societies by means of the Ethnographic Atlas, since this particular form of inheritance is not included in the codes. Instead, we turned to the Ethnographic Survey of Africa, published by the International African Institute. From this, it was possible to collect a sample of 93 societies which appeared both in the Atlas and the Survey ${ }^{2}$ and upon which there was sufficient information; the majority of these societies were patrilineal, though a few were bilateral; matrilineal systems were excluded since the house-property complex is necessarily absent from them. We then distinguished among the societies according to the presence of lateral inheritance, lineal inheritance-where sons inherit but there is no houseproperty complex-and the house-property complex. ${ }^{3}$

The house-property complex is clearly a particular type of vertical (or lineal) inheritance; it occurs in two geographical areas (Map 2), the first in South Africa among the Nguni, Sotho, and Venda peoples and among the Ngoni offshoots further north (but not among the patrilineal peoples of Central Africa, such as the Shona and Thonga), and secondly among the majority of the peoples of North-East Africa. As a means of distributing the major types of productive property within a society, it does not seem to occur either in West Africa or the Congo, though the Congo has a considerable number of patrilineal societies with vertical inheritance. However, one does find it applied to special forms of property in some West African peoples (e.g. to the 'compound farm' among the LoWiili; Goody, 1956:33-4), and there are some reports of the institution from sources other than the Ethnographic Survey (e.g. the Tiv and the Yoruba).

Clearly there is a fit between female farming and the house-property complex; the land a woman farms is distributed to her offspring. In Table 5 we see the strong association between the house-property complex and the sexual division of labour in cultivation $\left(X^{2}=5 I \cdot 19\right)$. However, we must look at the woman's contribution to farming in the context of the whole economy. Where men are concerned primarily with cattle, the women are likely to be concerned with cultivation. So that we also find a definite association between the house-property system and the distribution of

1 Worsley and Gluckman have criticized Fortes for his concern with opposing principles (Worsley, 1956:57) but agree on the importance of the group of full siblings and their mother as a unit of economic organization, relating this to the house-property complex.

2 We also included 5 peoples from South Africa specifically mentioned by Gluckman as having the house-property complex in his original discussion (r 950). These peoples (Xhosa, Pondo, Pedi, Venda, and Tembu) are not at present covered in the Ethnographic Survey.

3 The second category, lineal inheritance, is something of a residual category; since detailed information was not always available, it may well include some societies with the house-property system. 
large animals; the area of Gluckman's 'house-property complex' is the same as the area of Herskovitz's 'cattle complex'. As Aberle has pointed out, the cow is the enemy of matriliny (1961: 680). Indeed matriliny occurs mainly in areas infested by tsetse where it is impossible to keep cattle. In these cattle-keeping patrilineal societies,

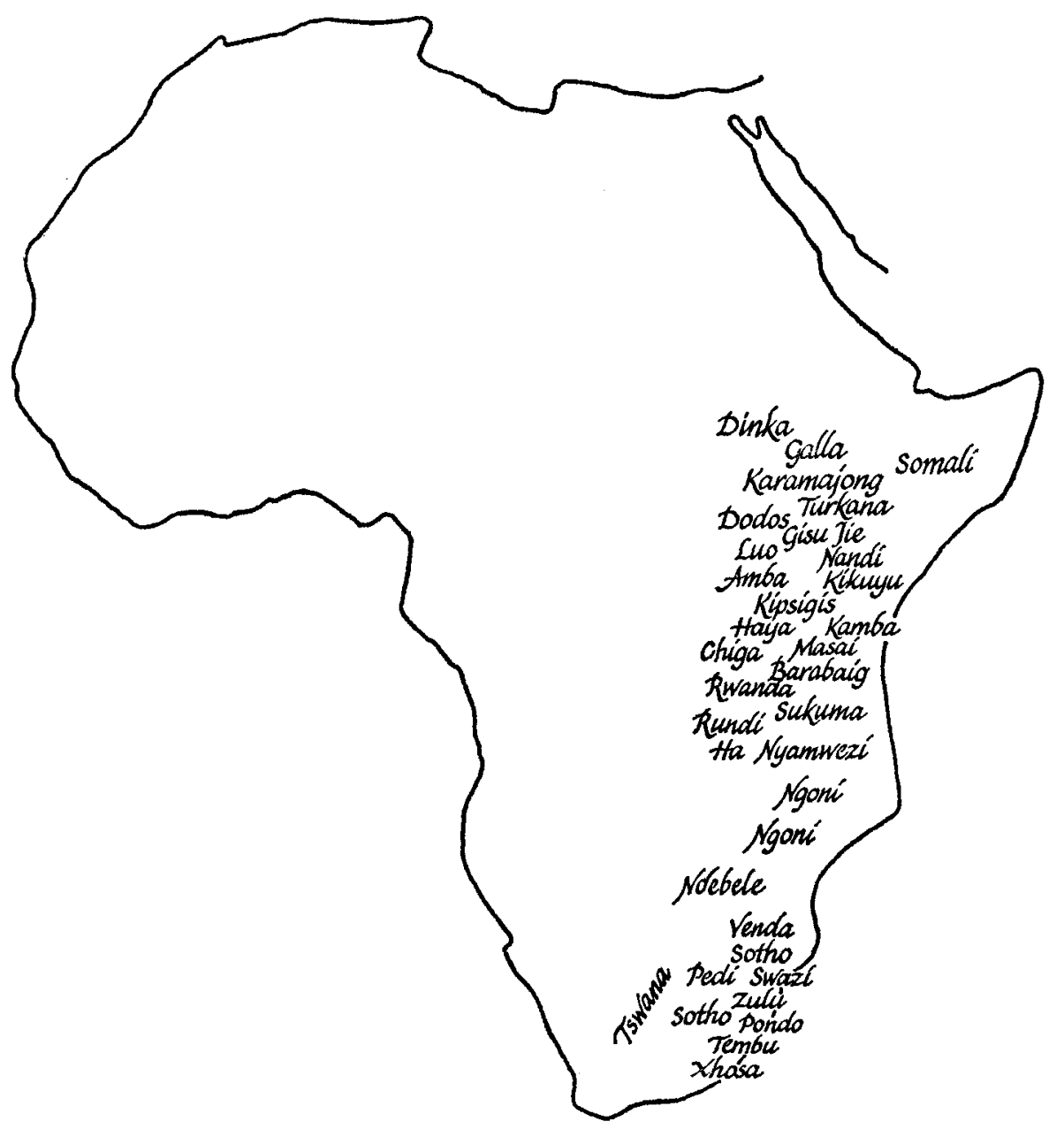

MAP 2. The house property complex in Africa (based on the Ethnographic Survey and Gluckman I950).

where men are engaged in herding and hunting, women are the main farmers and land is distributed through them, not 'matrilineally' but 'patrilineally' (Table VI). This is not true of the savannah areas of West Africa, where men do all except the vegetable farming and women are freer to take part in trade. It is significant that among the LoWiili of Northern Ghana it is only the small area of the compound farm where the woman grows her vegetables that is the subject of transmission per stirpes. 
We offer one comment upon the main exceptions to Table V. The two groups where men do the farming and yet inherit according to the house-property system are sub-groups of the Eastern Galla. These are pastoralists and it was mainly slaves who carried out the farming. Free Galla spent much of their time herding cattle; the women milked and helped with the herding. The equal contribution with house property (VI) occurs mainly among the predominantly pastoral Nilotics, as well as in Ruanda and Rundi. The two cases of men farming with lineal inheritance are the Songhai and the Kanembu of the West African savannahs.

$$
\begin{gathered}
\text { TABLE } \mathrm{V} \\
\text { House-property complex and division of labour in agriculture in Africa }
\end{gathered}
$$

\begin{tabular}{cllll}
\hline \multirow{4}{*}{} & \multicolumn{4}{l}{ Major part in cultivation played by: } \\
\cline { 2 - 5 } & Women & Equal & Men & Total \\
\hline House- & 24 & 6 & 2 & 32 \\
property & $(75 \%)$ & $(19 \%)$ & $(6 \%)$ & \\
Lineal & 17 & 13 & 2 & 32 \\
Inheritance* & $(53 \%)$ & $(41 \%)$ & $(6 \%)$ & \\
Lateral & 0 & 6 & 17 & 23 \\
Inheritancet & - & $(26 \%)$ & $(74 \%)$ & $(100 \%)$ \\
$\mathrm{X}^{2}=5 \mathrm{I} \cdot 19$ & & Total of Table & 87 \\
$\mathrm{P}<$-001 & & No Agriculture & 3 \\
& & N.I. on Division of Labour & 3 \\
\hline
\end{tabular}

N.B. Codes: Inheritance coded on information given in Ethnographic Survey, Division of Labour as in Table $\mathrm{x}$.

* In general the information given in the Ethnographic Survey on the Division of Labour agrees with the Atlas. In a number of cases this is not so. The only category affected to any great extent is that of Lineal Inheritance which on our teading of the Ethnographic Survey would give $13(4 \mathrm{r} \%)$ Female Dominance and $17(53 \%)$ Equal Participation.

† The figures for Lateral Inheritance are slightly better than expected because none of the 14 cases of Lateral Inheritance with Female Farming in Table 4 have sufficient information or do not appear in the Ethnographic Survey, and hence are excluded from this table.

In this connection, we would observe that the house-property system is not confined to agricultural societies; it is also found in some essentially pastoral economies, such as the Masai and Somali. In these societies, the herds, not the land, constitute the basic productive resources. The herds fall of course under the over-all care of men. But women often participate equally in animal husbandry, especially the milking; indeed, among the Nuer, men cannot milk. For example, Lewis describes how a Somali man allocates his animals among his wives who care for these separate herds and transmit rights of inheritance over them to their own children (1962:8-II). The same is clearly true of the Jie of Uganda and the Turkana of Kenya. Gulliver describes how the life and unity of a house are inextricably bound up with the ownership of domestic stock. The first intimation of the future splitting of the house is the 
allocation of animals to the wives of a polygynously married man. As the sons of these wives grow to adulthood, they identify themselves with the cattle, goats, and sheep of the 'yard' to which they belong; it is those animals which 'have been directly attended to by the mother' (1955: 84) that form the core of the new houses that emerge when the senior guardian dies (Jie) or when an elder brother marries out from his father's jurisdiction (Turkana). Thus 'the subdivision of a house into yards and its subsequent cleavage into new houses is based directly and consciously on maternal affiliation, yet the patrilineal principle is not thereby submerged. This appears quite clearly where inheritance is concerned, and inheritance provides the seed from which flowers the property-owning distinctiveness of the house. Groups

TABLE VI

House-property complex and domestic animals in Africa

\begin{tabular}{llll}
\hline & $\begin{array}{l}\text { Large } \\
\text { Animals }\end{array}$ & $\begin{array}{l}\text { Small or } \\
\text { no animals }\end{array}$ & Total \\
\hline House-property & $3 \mathbf{1}$ & 3 & 34 \\
& $(9 \mathrm{r} \%)$ & $(9 \%)$ & $(100 \%)$ \\
Lineal Inheritance & $\mathbf{1 4}$ & $\mathbf{2 1}$ & 35 \\
& $(40 \%)$ & $(60 \%)$ & $(100 \%)$ \\
Lateral Inheritance & 13 & 10 & 23 \\
& $(57 \%)$ & $(43 \%)$ & $(100 \%)$ \\
$\mathrm{X}^{2}=19.95$ & & Total of Table & 92 \\
$\mathrm{P}<.00 \mathrm{r}$ & & N.I. on Animals & $\mathrm{I}$ \\
& & & 93 \\
\hline
\end{tabular}

N.B. Codes: Inheritance as in Table 5. Animals are coded in Col. 39; B, C, D and E = Large animals; $\mathrm{O}, \mathrm{P}$ and $\mathrm{S}=$ Small or no animals.

of full-brothers inherit directly from their fathers, not from their mothers, for women are allowed no more than a limited usufruct of stock, and always at the discretion of their menfolk.' Wives or mothers 'are but differentiating links' (I955: 89). From the standpoint of the internal economy, however, women are more important than that, since they are allocated animals in order to provide the staple food, milk (p. I 28). The woman's position as a focus of differentiation within the agnatic family is related to her role in food production; she and her children will be identified with the section of the joint property which is allocated to her for productive purposes. She does not 'own' these resources but it is her children who benefit from those she and they have used. As with the land, so with cattle; hence here is an added reason why houseproperty is found in the area of the 'cattle complex'.

So far we have concentrated on patrilineal inheritance and its relation with the woman's contribution to the economy. Matrilineal inheritance is somewhat differently affected. In patrilineal societies, the distribution of lateral or lineal inheritance is influenced by the sexual division of labour. However, though matrilineal societies are more likely to have female predominance in cultivation, they are more likely to be lateral than are patrilineal ones (Goody, 1970). Of the 30 societies with matrilineal 
inheritance of land, 22 ( 73 per cent) have lateral transmission, that is, brothers inherit before sisters' sons; and there is a similar proportion in the transmission of movable property.

Why should matrilineal societies where female labour predominates be lateral when the similar patrilineal ones are lineal? In matrilineal societies in Africa, where men own the land, a woman cultivates either her brother's or her husband's land. In the first case, the land is automatically transmitted to her children; there is no need of any house-property complex, which is a characteristic only of societies with agnatic inheritance combined with plural marriage; a division between the sisters is a counterpart of division through the wives. On the other hand if she is cultivating her husband's land, then her children will not receive it in any case; they will benefit only from their mother's brother. Most matrilineal societies in Africa do practise virilocal residence; the woman cultivates land to which her children are not entitled. Hence the predominance of women in cultivation, although it is more widespread in matrilineal societies, does not directly affect the question of whether a brother or sister's son will inherit a man's property.

\section{Conclusion}

In this paper we have discussed some of the correlates of the dominant part played by women in African hoe cultivation. We find them making such a contribution in a wide range of societies, in states and in acephalous peoples, in all types of descent system. We do not see this fact as related to any one factor. The male contribution is much greater in the savannah country just south of the Sahara. Female farming predominates below this belt. It is strongly linked to two types of inheritance, firstly, matrilineal systems and secondly, with the form of vertical inheritance that Gluckman has called the house-property complex, which is again found with all types of political systems. Found in patrilineal and sometimes in bilateral societies, it divides male property among children on the basis of their maternal origin. In agricultural economies, such a system frequently assigns to a woman's sons the land which she has been farming but which she can neither possess nor transmit. In Eastern Africa, it is found primarily in areas where men are involved in herding large livestock while women farm. But it is also found among pastoral societies where women play a part either in tending or milking the cattle. The house-property complex therefore constitutes a kind of social recognition of a woman's major role in the process of production, though she herself is excluded from ownership of the means of production themselves. ${ }^{x}$

\section{Postscript}

In his most recent discussion of the house-property complex, Gluckman has related the type of property transmission to the strength and durability of the marriage tie. He argues that 'the situation of virtually no divorce and of the true levirate and sororate will be found with house-property filial inheritance, but there will be some divorce at least in systems with adelphic succession and inheritance' (1971 : 244). Adelphic inheritance is what we have called lateral inheritance.

I We are grateful to Professor M. Gluckman and Professor D. Forde for their comments and we thank the S.S.R.C. for their support of a comparative project. 
The data available in the Ethnographic Survey are too scanty to test every aspect of this argument; but the information for our sample of 93 societies does seem to offer some tentative support. Firstly, for divorce, the figures are as follows:

\section{TABLE VII}

Divorce and type of transmission of property

\begin{tabular}{lcccc}
\hline & Divorce & & \\
\cline { 2 - 5 } & Rare or Absent & Frequent & $\begin{array}{l}\text { No. indication } \\
\text { of rate }\end{array}$ & Total \\
\hline House-property & $21(66 \%)$ & $4(12 \%)$ & $7(22 \%)$ & $32(100 \%)$ \\
Lineal inheritance & $9(31 \%)$ & $6(21 \%)$ & $14(48 \%)$ & $29(100 \%)$ \\
Lateral inheritance & $10(43 \%)$ & $3(13 \%)$ & $10(43 \%)$ & $23(99 \%)$ \\
& & & N.I. on Divorce $\frac{9}{9}$ \\
& & & Total & 93
\end{tabular}

House-property transmission certainly has a much higher percentage of no (or rare) divorce, but with the lack of precise information on the other two categories, we cannot place much confidence in the result.

The same problem occurs when we look at widow inheritance.

TABLE VIII

Widow inheritance and type of transmission of property

\begin{tabular}{|c|c|c|c|c|c|}
\hline & \multirow[b]{2}{*}{ Absent } & \multirow[b]{2}{*}{$\begin{array}{l}\text { Type not } \\
\text { stated }\end{array}$} & \multicolumn{3}{|c|}{ Widow inheritance } \\
\hline & & & Non-leviratic & Leviratic & Total \\
\hline \multirow[t]{3}{*}{$\begin{array}{l}\text { House-property } \\
\text { Lineal inheritance } \\
\text { Lateral inheritance }\end{array}$} & $\begin{array}{l}\text { S }(20 \%) \\
1(4 \%)\end{array}$ & $\begin{array}{r}5(15 \%) \\
\text { Is }(60 \%) \\
\text { II }(48 \%)\end{array}$ & $\begin{array}{c}6(18 \%) \\
2(8 \%) \\
10(43 \%)\end{array}$ & $\begin{array}{l}23(68 \%) \\
3(12 \%) \\
1(4 \%)\end{array}$ & $\begin{array}{l}34(101 \%) \\
25(100 \%) \\
23(99 \%)\end{array}$ \\
\hline & & & \multicolumn{2}{|c|}{ N.I. on Widow inheritance } & II \\
\hline & & & \multicolumn{2}{|l|}{ Total } & $\overline{93}$ \\
\hline
\end{tabular}

Here again the hypothesis receives some support. House-property tends to be associated with the leviratic inheritance of widows, while with lateral or adelphic transmission, widow inheritance is unlikely to take this form.

Regarding the sororate, the position is similar; $4^{8}$ per cent of societies with the house-property system have the sororate, 26 per cent of the lateral and I9 per cent of the lineal. But all three have a similar percentage of societies where the sororate is stated to be absent ( 8 per cent). Again the lack of information in lateral and lineal categories means that we have to be particularly careful in interpreting these figures. ${ }^{I}$

I Societies with the house-property system are the best documented as regards marriage, divorce, the levirate and the sororate. 
Gluckman also suggests that 'in house-property systems wives are suspected of witchcraft, since struggles over position and property within agnatic groups focuses on them, as against the situation in patrilineal societies where there is adelphic succession and men are the focus of such struggles' (1971 : 243) and he finds some confirmation in Middleton and Winter's account of witchcraft in East Africa ( 1963 : I6I). It would be of great interest to test this hypothesis more systematically, but unfortunately we do not find the material in the sources we have used and, given the difficulty of accumulating a satisfactory quantity of information on such accusations from any one society, we doubt if it will ever be available. Obviously the rate of witchcraft accusations between co-wives depends upon the presence of polygyny (wives of roughly equal status), and probably upon the rate of plural marriage; hence it is likely to be much more frequent in Africa than elsewhere. And as Gluckman points out, logically one would expect the conflicts between co-wives to be greater when property is distributed among the children per stirpes rather than per capita, i.e. when it matters for inheritance, succession, or other tights whether you are the offspring of one wife rather than another. For this system will intensify not only the widespread jealousy of co-wives but also the actions attributed to them in attempting to secure the preferment of their own children over those of other women; it is the tension between the 'mother's children' and 'the father's children' to which Fortes has drawn attention. Where evil characteristics such as witchcraft are seen as passed down the uterine rather than the paternal line, the potential opposition between such groups of siblings is yet greater. While the house-property system does not involve transmission of this kind, it does focus attention on the differentiation between wives and their children, as typified in the 'house' system of the Zulu, with its numerical ordering of wives and their categorization into left and right, which is associated with the physical lay-out of their huts.

This evidence is certainly not conclusive, but as a whole it does lend some support to Gluckman's thesis, that marriage is a more enduring and stable bond in those polygynous, patrilineal societies that distribute property through wives, that is, by the house-property system, which we have in turn associated with the contribution made by women to agriculture and to animal husbandry. ${ }^{\mathrm{I}}$

\section{REFERENCES}

ABERLE, D. I96x. 'Matrilineal descent in cross-cultural perspective', in Matrilineal Kinship (eds.) Schneider D. M. and Gough, K. San Francisco.

BarNes, J. A. 1971. Three Styles in the Study of Kinship. London.

Boserup, E. 1970. Woman's Role in Economic Development. London.

Brown, J. K. 1970. 'A note on the division of labour by sex', American Anthropologist, 72, 1073-8.

Evans-Pritchard, E. E., 1940. The Nuer. Oxford. 1951. Kinship and Marriage among the Nuer. Oxford.

FIRTH, R. 1936. We, the Tikopia. London.

Fortes, M. 1949. The Web of Kinship among the Tallensi. London.

GluCKMAN, M. I950. 'Kinship and marriage among the Lozi of Northern Rhodesia and the Zulu of Natal', in African Systems of Kinship and Marriage (eds.) Radcliffe-Brown, A. R. and Forde, D. London.

In view of the positive association of prohibitions of pre-matital sex with another type of direct or lineal system of inheritance, namely diverging devolution, it should be added that in 2 I of the 34 societies with house-property $(62 \%)$, there are sanctions on pre-marital sex-in ro cases the bride is expected to be virgin, in the other I I cases limited sexual relations are allowed but the girl faces severe sanctions if she becomes pregnant. There is hardly any information on attitudes towards pre-marital sex for the societies with lineal and lateral inheritance. 
- 1971. 'Marriage payments and social structure among the Lozi and the Zulu (postscript I971)', in Kinship: Selected Readings (ed.) Goody, J. London.

Goodr, J. 1956. The Social Organisation of the LolWiili. London.

- 1969. 'Inheritance, property and marriage in Africa and Eurasia', Sociology, 3, 55-76.

- 1970. 'Sideways or downwards? Lateral and vertical succession, inheritance and descent in Africa and Eurasia', Man, 5, 627-38.

Gulliver, P. H. I959. The Family Herds. London.

HuNTER, M. 1936. Reaction to Conquest. London.

Lestrange, M. de. 1955. Les Coniagui et les Bassari. Paris.

Lewis, I. M. 1962. Marriage and the Family in Northern Somaliland. (East African Studies No. 15). Kampala.

Mrtchell, J. C. I950. 'Preliminary notes on land tenure and agriculture among the Machinga Yao', Human Problems in British Central Africa, Io, I-13.

MurDock, G. P. 1967. 'The ethnographic atlas : a summary', Ethnology, 4, 109-236.

- I968. 'The current status of the world's hunting and gathering peoples', in Man the Hunter (eds.) Lee, R. B. and DeVore, I. Chicago.

Robertson, G. S. 1896. The Kafirs of the Hindu-Kush. London.

SchneIder, D. M. r965. 'Some muddles in the models', in The Relevance of Models for Social Anthropology. London.

Stauder, J. 1971. The Majangir. Cambridge.

STEWARD, J. 1968. 'Causal factors and processes in the evolution of pre-farming societies', in Man the Hunter (eds.) Lee, R. B. and DeVore, I. Chicago.

Wrlinams, S. N. 1971. 'The limitations of the male/female activity dimension among primates', American Anthropologist, 73, 805-6.

WorsLey, P. M. I956. 'The kinship system of the Tallensi : a revaluation,' J.R. Anthrop. Inst., 86, 37-75.

\section{Résumé}

\section{HÉRITAGE ET TRAVAIL DES FEMMES EN AFRIQUE}

EN Afrique, les femmes jouent souvent un rôle important dans les activités agricoles. L'exploitation par les femmes prédomine au Congo, en Afrique centrale, orientale, et en Afrique du Sud, alors que l'importance des femmes dans l'agriculture décline en Afrique du Nord et de l'Ouest. L'exploitation agricole par des femmes est fortement liée à deux types de succession, d'abord aux systèmes matrilinéaires, ensuite à la forme de succession verticale que Gluckman a nommée 'house-property'. On la trouve dans les sociétés patrilinéaires et parfois les sociétés bilatérales. Le système 'house-property' divise la propriété des hommes entre les enfants selon leur origine maternelle. Dans les économies d'agriculture, un tel système attribue fréquemment aux fils d'une femme la terre qu'elle a eue en fermage, mais qu'elle ne peut ni posséder ni transmettre. Le système 'house-property' se rencontre dans les grandes zones d'élevage d'Afrique; les hommes s'occupent des troupeaux et les femmes de l'exploitation agricole. Il peut en être de même dans les sociétés purement pastorales où les femmes jouent un rôle en soignant ou en trayant le bétail. Le système 'houseproperty' fournit par conséquent une sorte de reconnaissance sociale du rôle important de la femme dans le processus de production, bien qu'elle soit elle-même exclue de la possession des moyens de production. 